\title{
Effects of Post Weld Heat Treatments on the Microstructure and Mechanical Properties of Dissimilar Weld of Supermartensític Stainless Steel
}

\author{
Sérgio Souto Maior Tavares ${ }^{a *}$, Clóvis Ribeiro Rodrigues ${ }^{a}$, Juan Manuel Pardal, \\ Edvan da Silva Barbosa ${ }^{a}$, Hamilton Ferreira Gomes de Abreu ${ }^{b}$ \\ ${ }^{a} P G M E C$, Escola de Engenharia, Universidade Federal Fluminense - UFF, \\ Rua Passo da Pátria, 156, CEP 24210-240, Niterói, RJ, Brazil \\ ${ }^{b}$ Departamento de Engenharia Metalúrgica e Materiais, Universidade Federal do Ceará - UFC, \\ Fortaleza, CE, Brazil
}

Received: May 31, 2014; Revised: October 5, 2014

\begin{abstract}
A supermartensitic stainless steel with composition $12.2 \% \mathrm{Cr}-5.8 \% \mathrm{Ni}-1.90 \% \mathrm{Mo}-0.028 \% \mathrm{C}$ (\%wt.) was welded by gas tungsten arc welding (GTAW) with superduplex stainless steel filler metal. Post weld heat treatments (PWHT) at $650{ }^{\circ} \mathrm{C}$ for different periods of time were performed in order to decrease the hardness in the heat affected zone (HAZ). This paper deals with the effect of these heat treatments on the microstructure and mechanical properties of the joint. Mechanical strength of the weld joint was slightly inferior to the base metal, but was not affected by heat treatments. Precipitation of intermetallic phases in the weld metal (WM) due to prolonged PWHT was detected by scanning electron microscopy. The impact toughness of the weld metal decreased with the increase of time of heat treatment, due to intermetallic precipitation. However, even in the specimen treated for $1 \mathrm{~h}$, the Charpy energy remained above $27 \mathrm{~J}$ at $-46^{\circ} \mathrm{C}$. It was found that optimum mechanical properties can be obtained with heat treatment for 30 minutes at $650{ }^{\circ} \mathrm{C}$.
\end{abstract}

Keywords: supermartensitic stainless steel, dissimilar weld, post weld heat treatment

\section{Introduction}

Supermartensitic stainless steels (SMSS) are a new generation of martensitic stainless steels developed for a better corrosion resistance and toughness. The first generation of SMSS contained $11-13 \% \mathrm{Cr}$, Mo and $\mathrm{Ni}$ additions $^{1}$. Other compositional features of this class of steel are the extra low carbon $(<0.03 \%$ wt. $)$ and extremely low impurity levels. Recently, $\mathrm{Ti}, \mathrm{Nb}, \mathrm{V}$ and $\mathrm{Cu}$ have been used to improve mechanical and corrosion resistance properties of some grades. Steels with such complex chemical compositions may present not only martensite but also austenite and ferrite, depending on the fabrication processes. For instance, tempering above $\mathrm{A}_{\mathrm{cl}}$ or double tempering introduces considerable amounts of interlath and intergranular austenite in the microstructure ${ }^{2,3}$.

The strong reduction of carbon content also envisages the improvement of the weldability of $\mathrm{SMSS}^{2}$. Conventional martensitic steels, such as AISI 420 and 410, are susceptible to cold cracking due to the hard martensite formed in the HAZ. Welding procedures of theses grades usually include pre-heating, post-heating and post weld heat treatments (PWHT). The extra low carbon martensite of $13 \% \mathrm{Cr}$ SMSS is much softer and its toughness is considerably higher than conventional martensitic grades ${ }^{4}$.

SMSS may be welded with similar or dissimilar filler metals. Bala Srinivasan et al. ${ }^{5}$ studied the hydrogen assisted cracking of SMSS welded with overmatched filler

*e-mail: ssmtavares@terra.com.br metal. The welds produced by electron beam welding (EBW) without pre-heating were heat treated at $630{ }^{\circ} \mathrm{C}$ for 30 minutes. Despite of this treatment, the hardness in the weld metal was relatively high $(350 \mathrm{HV})$, resulting in hydrogen induced cracking, as observed by slow strain rate tensile tests.

Pereda et al. ${ }^{6}$ studied the corrosion resistance of SMSS $13 \% \mathrm{Cr}$ steel welded with submerged arc welding (SAW) with similar feed metal, but Ni and Mo overmatched. Welding procedure did not include pre-heating neither PWHT. Due to the higher Mo content the weld metal showed a higher pitting corrosion resistance in electrochemical tests.

Gesnouin et al. ${ }^{7}$ and Bilmes et al. ${ }^{8}$ studied the effect of PWHT on corrosion, microstructure and mechanical properties of welds of $13 \mathrm{CrNiMo}$. In these works a higher amount of austenite was produced by double tempering $\left(670{ }^{\circ} \mathrm{C} / 2 \mathrm{~h}+600^{\circ} \mathrm{C} / 2\right.$ or $\left.8 \mathrm{~h}\right)$. Similar double stage treatment was performed in a soft martensitic steel $410 \mathrm{NiMo}$, promoting a significant improvement of toughness ${ }^{9}$. The authors attributed the high toughness obtained to the increase of austenite content.

Neubert et al. ${ }^{10}$ have studied several welded joints of $12 \% \mathrm{Cr}$ SMSS produced by high energy processes, and found a slight increase of hardness with short time post weld tempering in the $630-640{ }^{\circ} \mathrm{C}$ range. On the other hand, Thibault et al. ${ }^{11}$ measured a slight decrease of hardness in weld metal and heat affected zone (HAZ) in a $13 \mathrm{Cr}-4 \mathrm{Ni}$ 
(\%wt.) steel welded joint heat treated at $620{ }^{\circ} \mathrm{C}$. There are ambiguous results about the effect of PWHT in the literature.

According to Lippold and Kotecki ${ }^{12}$ SMSS may be welded with duplex (DSS) or superduplex stainless steel (SDSS) filler metals. The latter can produce deposits with higher mechanical resistance, closer to the base metal. PWHT may be required to stress relief the SMSS parent metal. However, there is a lack of information on the literature about this dissimilar welding procedures.

In this work multi-pass weld joints produced by GTAW process with SDSS filler metal and different PWHT at $650{ }^{\circ} \mathrm{C}$ were investigated. The main objectives were the characterization of the dissimilar weld joint and the evaluation of the effects produced by the PWHT.

\section{Experimental Procedures}

The base metal was a tube with $200 \mathrm{~mm}$ of diameter and $10 \mathrm{~mm}$ of thickness. The material was heat treated by quenching and tempering at $650{ }^{\circ} \mathrm{C}$ for 1 hour before welding. Table 1 shows the chemical compositions of base metal and superduplex filler metal. Tensile properties of the base metal are: Yield limit $\left(\sigma_{\mathrm{Y}}\right)=670 \mathrm{MPa}$, Ultimate tensile strength $\left(\sigma_{\text {UTS }}\right)=798 \mathrm{MPa}$, Elongation $\left(\%, \mathrm{~L}_{\mathrm{o}}=20 \mathrm{~mm}\right)=$ $23.1 \%$ and Reduction of area $(\%)=83.5 \%$.

The circumferential joint was produced by manual GTAW process, without pre-heating. The heat input was kept below $2.0 \mathrm{~kJ} / \mathrm{mm}$. Pure argon (99.9\%) was used as protection and purge gas. Radiographic test was carried out 48 hours after welding to evaluate the soundness of the joint.

The weld joint was cut by cold method into pieces for microhardness, hardness, tensile and impact Charpy tests. These pieces were heat treated at $650{ }^{\circ} \mathrm{C}$ for 15 , 30,45 and 60 minutes with rapid cooling in water. After these treatments some samples were machined to the final dimension of sub-size ( $7.5 \mathrm{~mm}$ thickness) and V-notched Charpy impact specimens ${ }^{13}$ and tensile test specimens with gauge length $25.0 \mathrm{~mm}^{14}$. The specimens for microhardness and hardness tests were also machined with both sides parallel.

Charpy impact tests were carried out at $-46{ }^{\circ} \mathrm{C}$ temperature while tensile tests were conducted at room temperature. Three Charpy and tensile tests per condition were performed, and average values will be presented.

Vickers microhardness with $100 \mathrm{gf}$ load and hardness (15 kgf load) cross section profiles, in the root pass and last pass regions, were measured in the as welded condition. Since the microhardness and hardness profiles of the as welded sample were very similar, as will be shown, only hardness profiles were measured in the heat treated welds.

Microstructural characterization included light optical (LOM) and scanning electron microscopy (SEM). The specimens for LOM of superduplex weld metal were prepared with Beraha's etching $(20 \mathrm{ml} \mathrm{HCl}, 80 \mathrm{ml}$ distilled water and $0.4 \mathrm{~g}$ of potassium metabissulfite). The heat affected zone (HAZ) was prepared with Villela's reagent (90 $\mathrm{ml}$ ethanol, $10 \mathrm{ml} \mathrm{HCl}$ and $1 \mathrm{~g}$ of picric acid). Austenite and ferrite volume fractions in the weld metal (WM) were determined by quantitative metallography according to ASTM E-562 standard $^{15}$ using 20 fields by region.

\section{Results and Discussion}

Figure 1 shows the macrostructure of the weld joint. The radiographic test did not detect any defect in the circunferential weld.

Figures $2 \mathrm{a}$ and $\mathrm{b}$ show the microhardness and hardness profiles of root pass and last pass of the as welded specimen. It can be noted that very similar results were obtained with microhardness (100 gf load) and hardness (15 kgf load) tests. In the root pass region the weld metal is harder than the heat affected zone and base metal, while in the last pass region a peak of hardness is observed in the heat affected zone. The peak hardness in the HAZ of the last pass of the as welded specimen is $365 \mathrm{HV} 15$, which is considerably higher than the average of base metal ( 300 HV30). The peak of hardness is not observed in the root pass because the filling passes promote the tempering of this region of the HAZ. Differently, in the last pass there was no subsequent passes enough to decrease the hardness of the HAZ. Ramirez ${ }^{16}$ studied the weld of supermartensitic steels and also observed the increase of hardness of the HAZ from the root to the cap region of the joint. Yayla et al. ${ }^{17}$ also observed the peak of hardness in the HAZ of the cap passes of a low alloy HY-80 steel.

Figures 3a-d show typical microstructures observed in the as welded specimen. Figure 3 a shows the HAZ with a typical martensitic structure and TiN particles, without $\delta$-ferrite. Figures $3 b$-d are from the three regions of the WM indicated in Figure 1, i.e., root pass, middle and last pass.

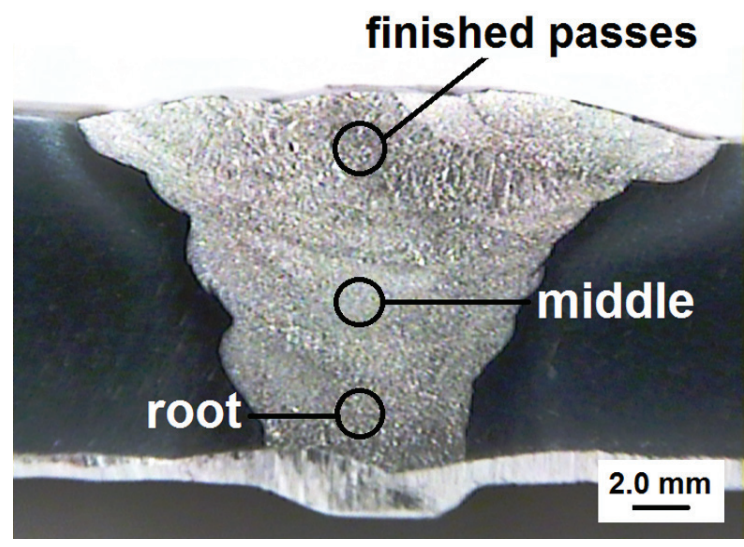

Figure 1. Macrostructure of the weld produced.

Table 1. Chemical compositions of base and filler metals (wt $\%)$.

\begin{tabular}{llllllllll}
\hline \multicolumn{1}{c}{ Material } & $\mathbf{C}$ & $\mathbf{C r}$ & $\mathbf{N i}$ & $\mathbf{M o}$ & $\mathbf{M n}$ & $\mathbf{T i}$ & $\mathbf{P}$ & $\mathbf{S}$ & $\mathbf{N}$ \\
\hline Base metal & 0.0278 & 12.21 & 5.8 & 1.95 & 0.52 & 0.28 & 0.112 & 0.002 & 0.013 \\
Filler metal & 0.012 & 24.56 & 9.1 & 3.65 & 0.40 & - & 0.080 & 0.001 & 0.275 \\
\hline
\end{tabular}




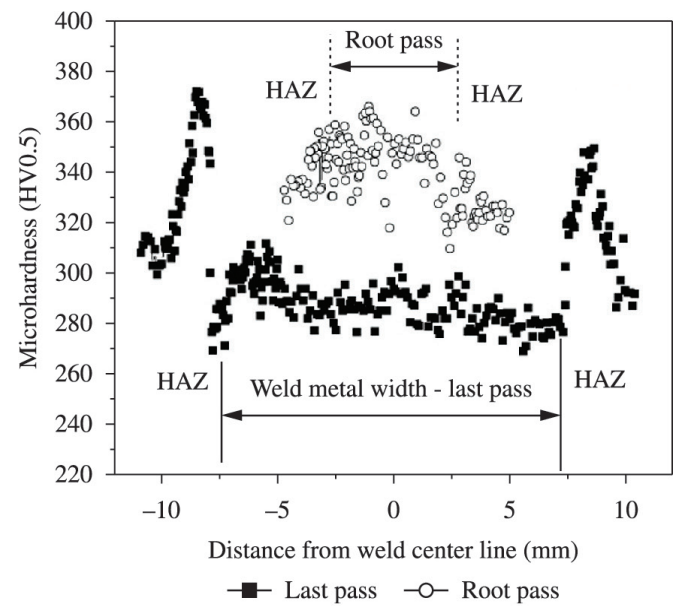

(a)

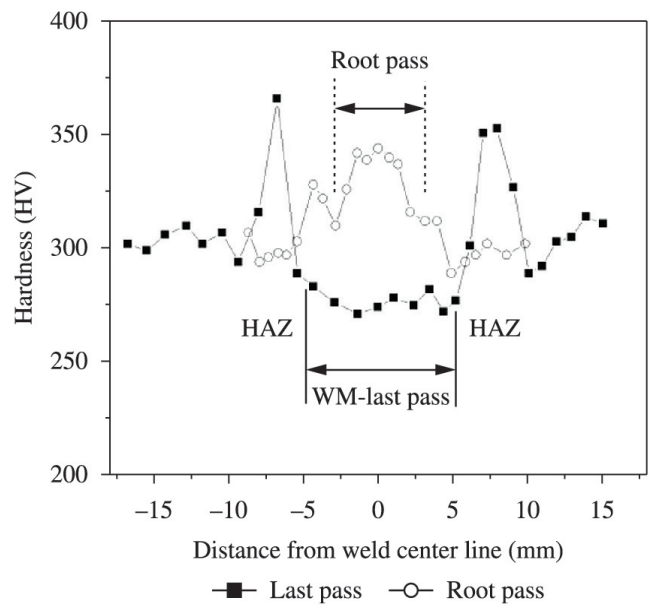

(b)

Figure 2. (a) Microhardness and (b) hardness profile of the weld joint (root and last pass), as welded.

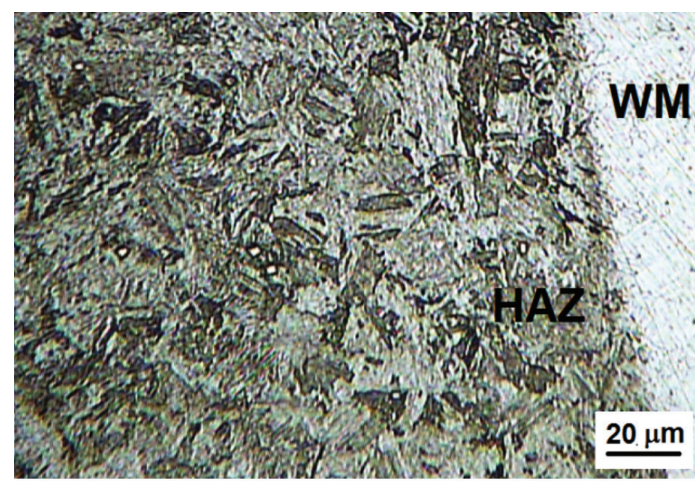

(a)

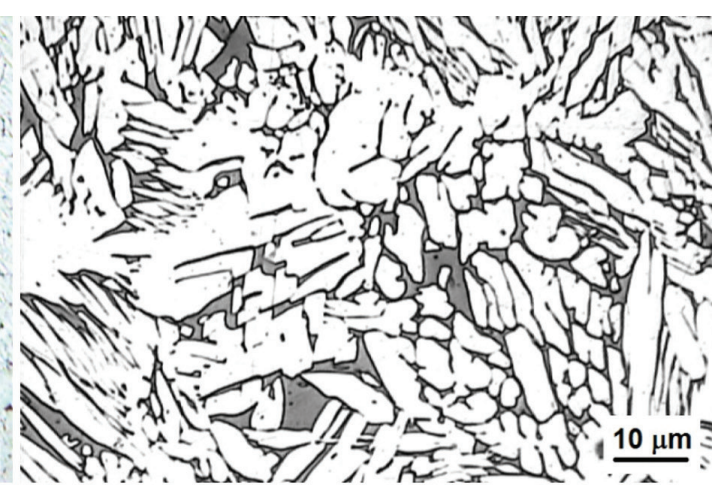

(b)

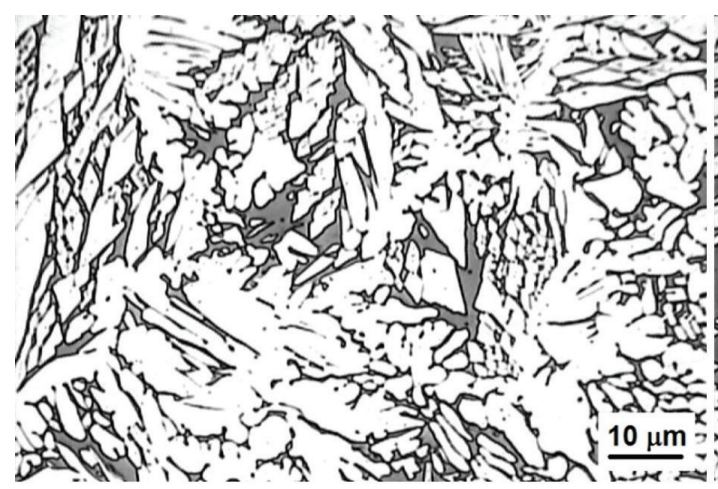

(c)

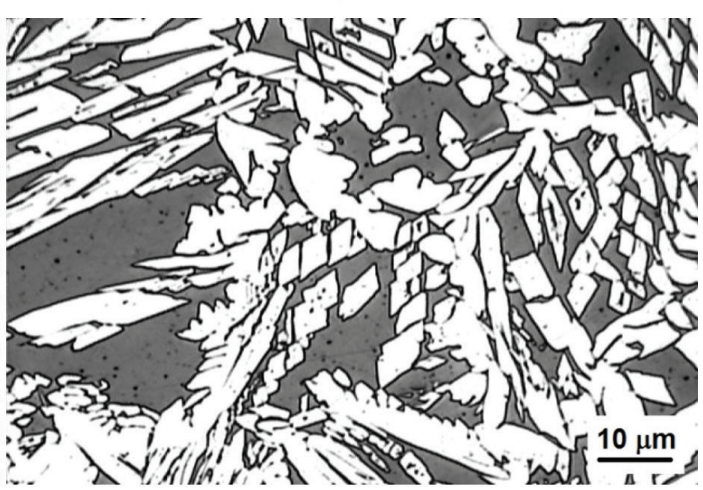

(d)

Figure 3. Microstructures of as welded specimens: (a) HAZ; (b) weld metal-root; (c) weld metal-middle; (d) weld metal-finished pass.

The chemical compositions of the three regions of Figure 1 were determined by EDX in the scanning electron microscope (SEM). Carbon, nitrogen and sulfur were determined by combustion with sparks from the root and last pass. These elements could not be analyzed in the middle region, but, as a rough approximation, they were considered as the average of the root and last passes. Table 2 shows the estimated chemical compositions of the three regions. From these values the $\mathrm{Cr}_{\text {eq. }}$ and $\mathrm{Ni}_{\text {eq. }}$ were calculated according to the WRC-1992 diagram ${ }^{12}$ (also shown in Table 2). Table 3 compares the predicted austenite fraction determined according to WRC-1992 diagram with the actual values measured by quantitative metallography. The austenite volume fraction measured by metallography is considerably higher than the prediction, mainly for the finish passes. The root and the middle passes have more austenite than the last passes, probably due the higher $\mathrm{Cr}$ and $\mathrm{Mo}$ and lower $\mathrm{Ni}$ and 


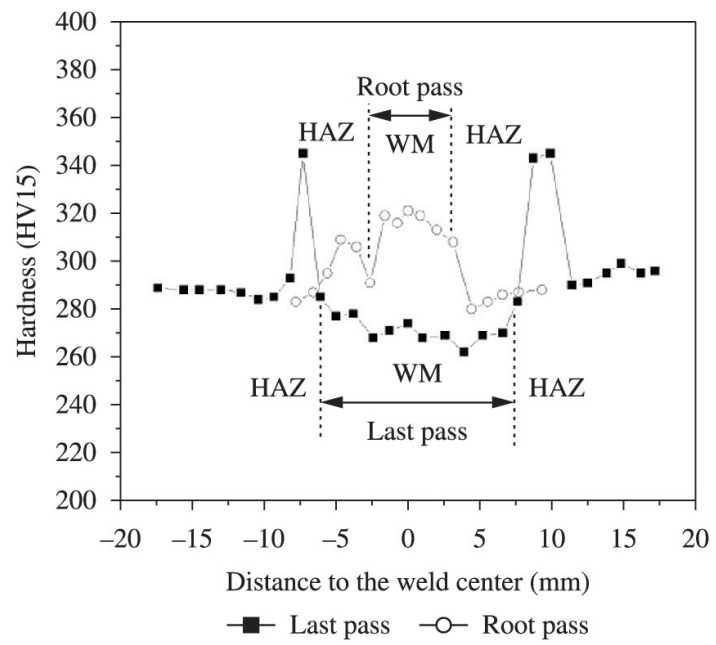

(a)

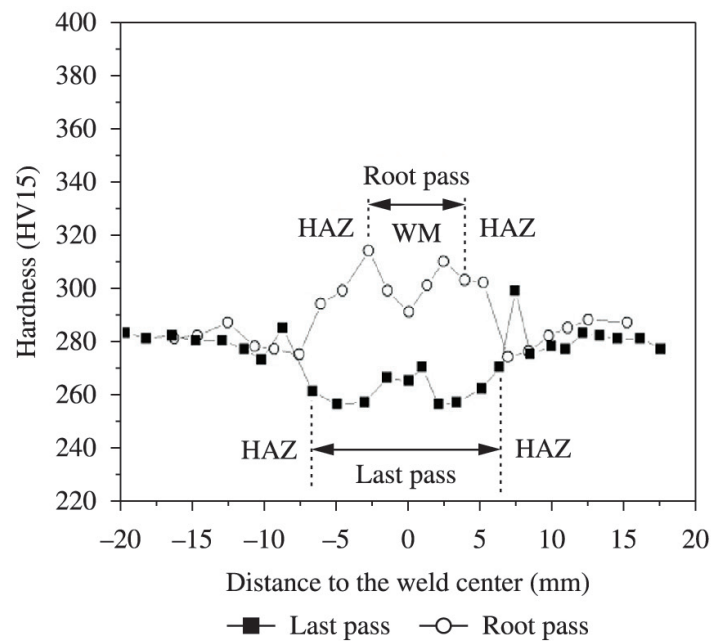

(c)

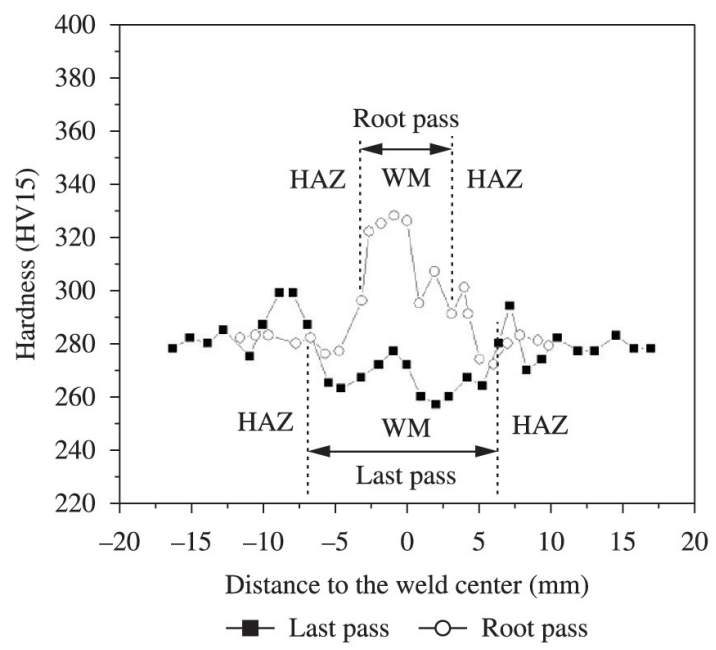

(b)

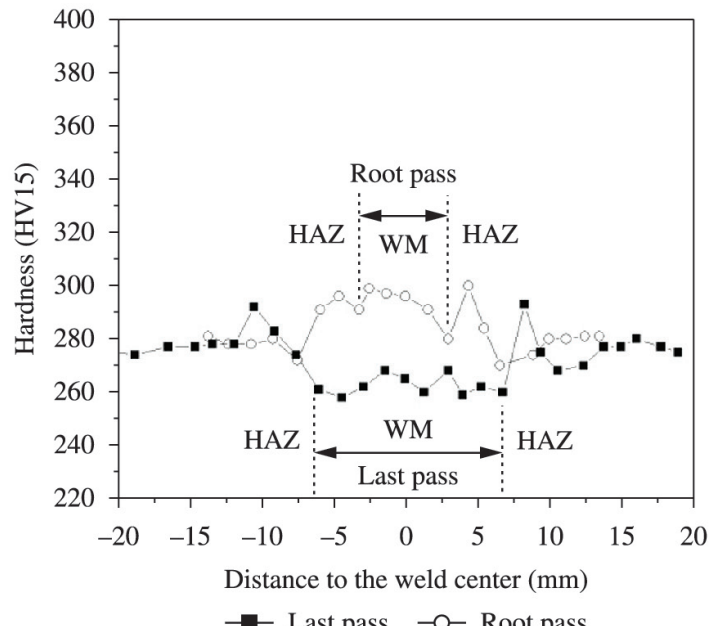

Last pass $-0-$ Root pass

(d)

Figure 4. Hardness profiles of specimens heat treated at $650^{\circ} \mathrm{C}$ for: (a) $15 \mathrm{~min}$.; (b) $30 \mathrm{~min}$.; (c) $45 \mathrm{~min}$.; and (d) $60 \mathrm{~min}$.

Table 2. Estimated chemical compositions of regions of the weld metal (see Figure 1). $\mathrm{Cr}_{\mathrm{eq}}$ and $\mathrm{Ni}_{\mathrm{eq}}$ calculated according to ${ }^{12}$.

\begin{tabular}{lcccccccc}
\hline \multicolumn{1}{c}{ Region } & $\mathbf{C r}$ & $\mathbf{M o}$ & $\mathbf{N i}$ & $\mathbf{C}$ & $\mathbf{N}$ & $\mathbf{S}$ & $\mathbf{C r}_{\text {eq. }}$ & $\mathbf{N i}_{\text {eq. }}$ \\
\hline Root pass & 22.29 & 3.76 & 8.37 & 0.0169 & 0.2297 & 0.001 & 26.05 & 13.56 \\
Middle & 22.57 & 4.11 & 8.99 & $(0.0178)$ & $(0.2200)$ & $(0.001)$ & 26.68 & 14.01 \\
Finish pass & 24.53 & 4.10 & 8.60 & 0.0188 & 0.2104 & 0.001 & 28.63 & 13.50 \\
\hline
\end{tabular}

Table 3. Comparison between experimental and predicted austenite volume fraction.

\begin{tabular}{lcc}
\hline \multicolumn{1}{c}{ Region of WM } & WRC-1992 $^{9}$ & Experimental \\
\hline Root & 64 & $75.6 \pm 6.5$ \\
Middle & 64 & $75.2 \pm 7.4$ \\
Finish pass & 35 & $60.6 \pm 7.1$ \\
\hline
\end{tabular}

$\mathrm{N}$ in the chemical composition and also to the effect of reheating which promote the formation of secondary austenite.

It is worth noting that the weld metal of root pass is harder than the last pass, as shown in Figures $2 \mathrm{a}$ and $\mathrm{b}$. This can be attributed to the higher nitrogen content of the root pass which hardens the austenite. In duplex and superduplex steels the austenite is the harder phase.

Some problems may arise from the un-balanced microstructure in austenitic-ferritic stainless steels. If the weld metal contains much more austenite than ferrite it means that ferrite formers elements such as $\mathrm{Cr}$, Mo and $\mathrm{Si}$ will be more concentrated in this phase, which favors the precipitation of deleterious intermetallic compounds.

Figures $4 \mathrm{a}-\mathrm{d}$ shows the hardness profiles measured after the post weld heat treatments at $650^{\circ} \mathrm{C}$. The peak hardness in the HAZ in the region of the last pass and the maximum hardness of the weld metal in the root pass decrease with the increase heat treatment time, as shown in Figure 5. The 
peak hardness in the HAZ decreases to $299 \mathrm{HV}$ with heat treatment at $650{ }^{\circ} \mathrm{C}$ for 30 minutes. The decrease of peak hardness in the HAZ is one of the objectives of post weld heat treatments. The maximum limit value of $253 \mathrm{HV}$ has been adopted for high strength low alloy (HSLA) and carbon steels in sour service in oil and gas production, based on NACE 00175 standard $^{18}$. This limit exists to avoid sulphide stress corrosion cracking (SSCC). However, a hardness limit for other types of materials candidates to sour service conditions, such as duplex and supermartensitic stainless steels, must be more investigated, since $253 \mathrm{HV}$ seems excessively conservative for these classes of steels. The determination of a more realistic hardness limit for these materials depends on the understanding of the effects of $\mathrm{H}_{2} \mathrm{~S}$ on the mechanical properties and the interaction of hydrogen with the different microstructures of SMSS and SDSS.

The impact toughness of HAZ was not investigated in this work, due to the geometry of the bevel (V) and the thickness of the base metal $(10 \mathrm{~mm})$. However, previous work on the mechanical properties of base metal with the same composition has shown that high impact toughness at $-46{ }^{\circ} \mathrm{C}$ and very ductile behavior were observed with tempering at $650{ }^{\circ} \mathrm{C}$ for 1 hour $^{3}$. At this temperature the tempering reactions are basically chromium and molybdenum carbide precipitation and austenite formation.

The variation of impact energy in the weld metal with PWHT duration is shown in Figure 6. The values were corrected from sub-size $7.5 \mathrm{~mm}$ to standard $10.0 \mathrm{~mm}$ according to ASTM A-370-12 ${ }^{14}$. The impact toughness continuously decreased with the increase of heat treatment duration, but remained higher than the $27 \mathrm{~J}$ limit of Norsok M-601 standard ${ }^{19}$, even after 1 hour treatment. The fractographic analysis of all specimens after impact tests revealed ductile behavior with dimples, as shown in Figure 7.

The decrease of weld metal toughness may be explained by some evidences found in the microstructural analysis. As previewed, deleterious intermetallic compounds may precipitate in superduplex steels treated in the $1050-600^{\circ} \mathrm{C}$ interval of temperature. The images shown in Figures 8a-d are from the weld metal of specimens treated for 15, 30, 45 and 60 minutes. These images were obtained in SEM operating in the backscattering electrons (BSE) mode with specimens carefully polished and not etched. Based on previous works ${ }^{20-22}$, light precipitates are Mo rich phases, since this element is considerably heavier than the others and increases the average atomic number. The precipitates were too fine to be quantitatively or semi-quantitatively analyzed with EDS in the SEM, but a qualitative analysis with an image with $\sim 30000 \mathrm{X}$ of magnification (Figure 9) confirmed that the bright precipitates contained higher Mo than the ferrite and austenite phases. Small and circle pores (in black) were also observed in Figures 8a, c and d, but this was not the cause of the decrease of impact energy because they were also observed in the as welded specimen.

According to thermodynamic and kinetics predictions, there are some possibilities for the Mo-rich precipitates formed in the ferrite, including sigma, chi and $\mathrm{R}$ phases $^{12,20,22-26}$. Laves phase $\mathrm{R}\left(\mathrm{Fe}_{2} \mathrm{Mo}\right)$ precipitate in small quantities between 550 and $650{ }^{\circ} \mathrm{C}$, with a morphology

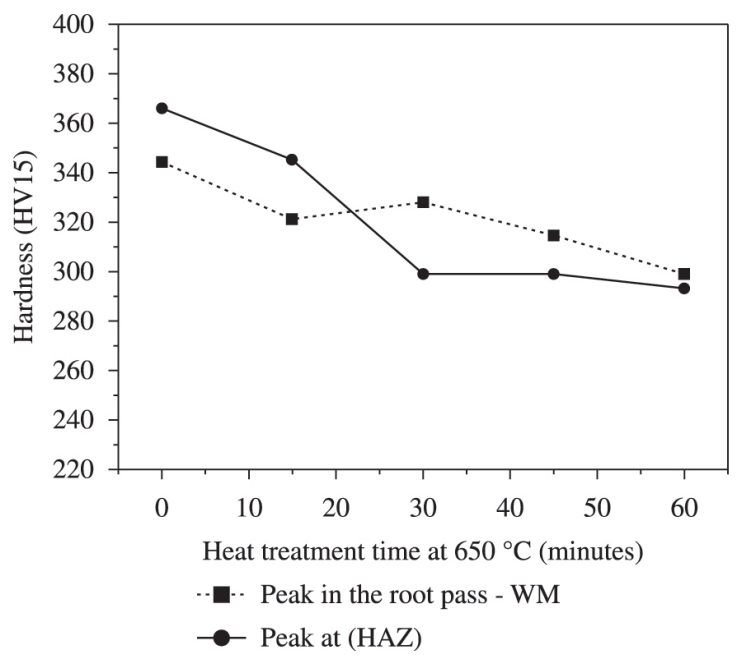

Figure 5. Variation of peak hardness with time of PWHT $\left(650^{\circ} \mathrm{C}\right)$.

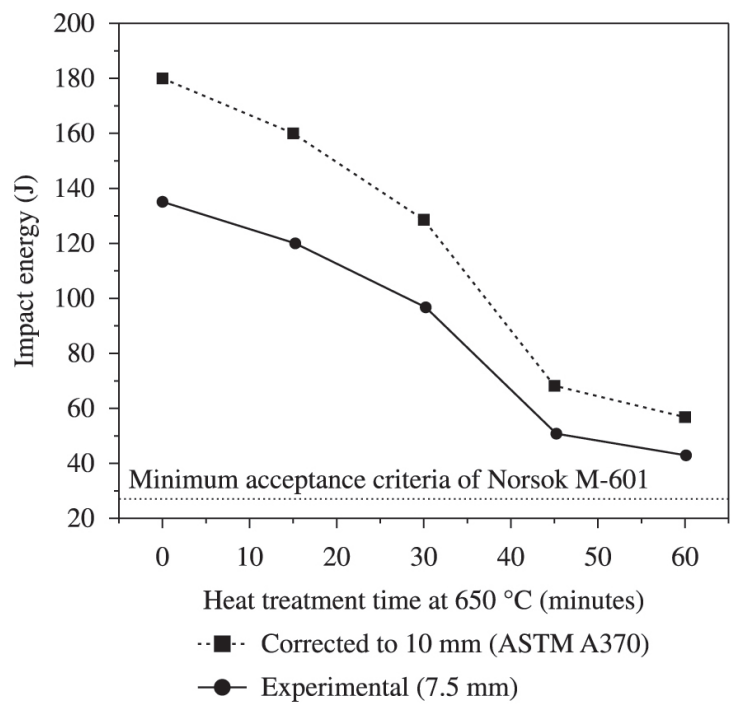

Figure 6. Variation of impact energy with time of PWHT $\left(650^{\circ} \mathrm{C}\right)$.

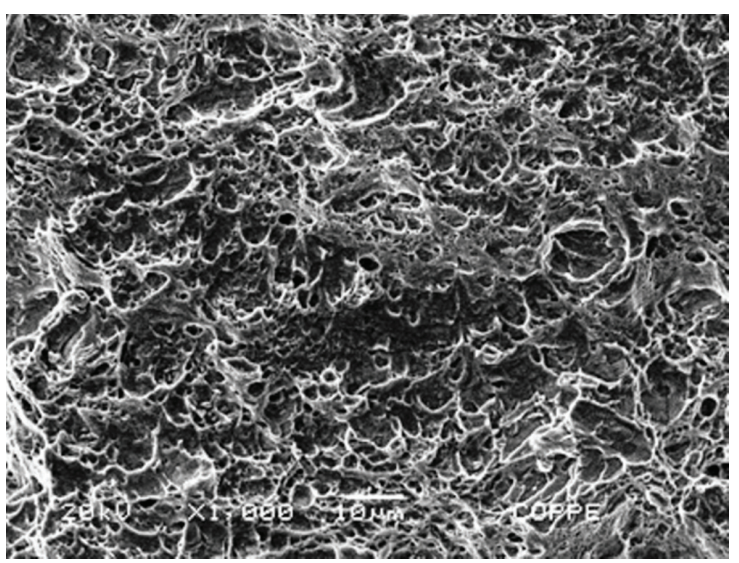

Figure 7. SEM image of specimen heat treated for 1 hour at 650 ${ }^{\circ} \mathrm{C}\left(42 \mathrm{~J}\right.$ at $-46{ }^{\circ} \mathrm{C}$ - sub-size specimen $\left.7.5 \mathrm{~mm}\right)$. 


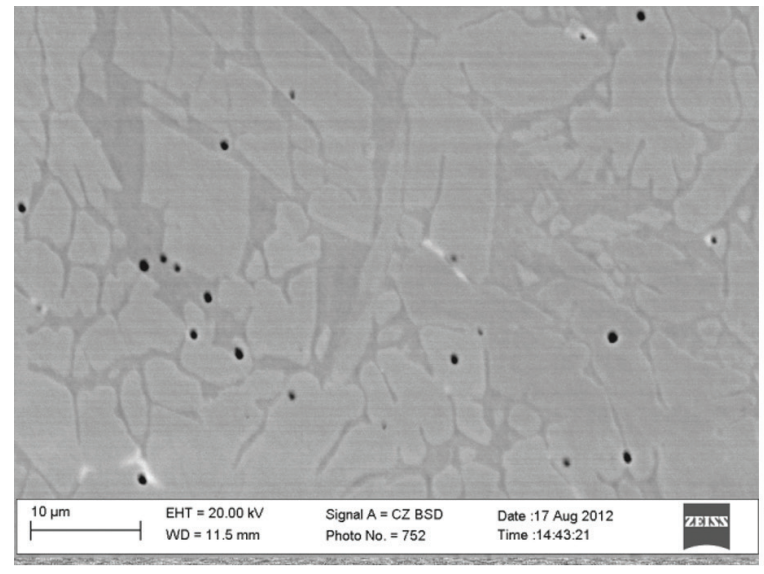

(a)

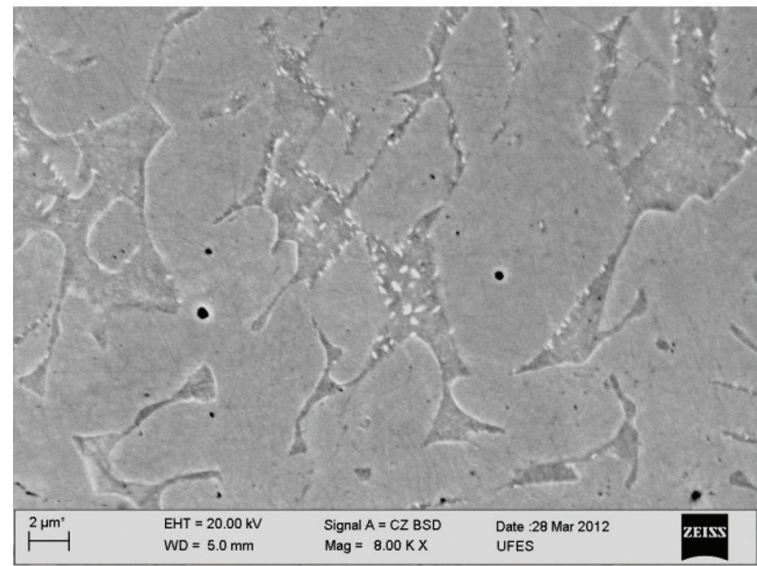

(c)

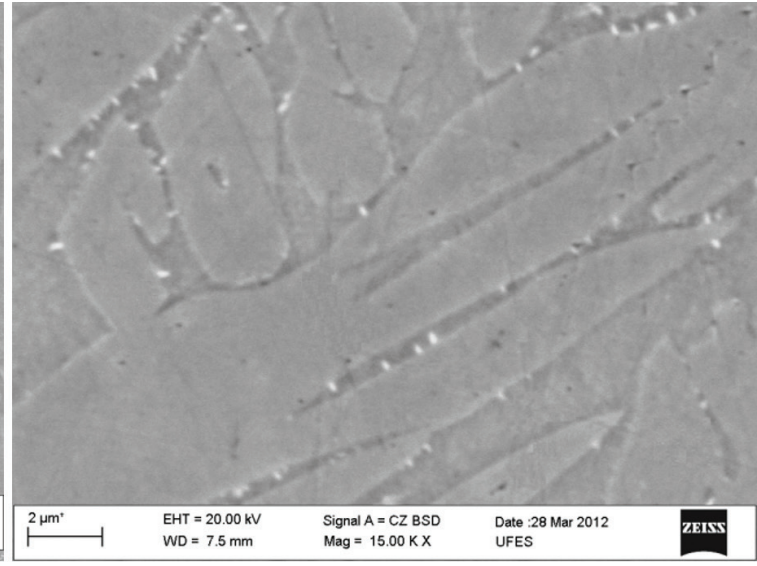

(b)

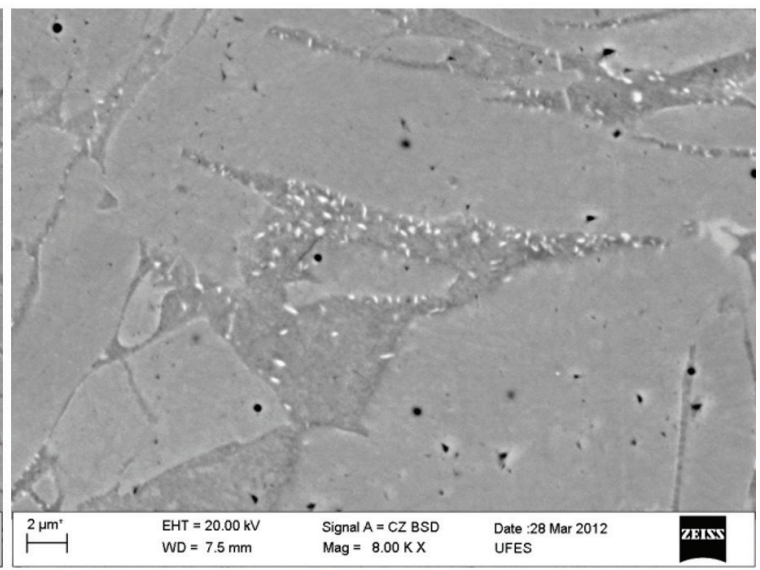

(d)

Figure 8. Microstructures of weld metal without etch (BSE mode) after PWHT at 650ㅇ: (a) 15 min.; (b) 30 min.; (c) 45 min.; (d) 60 min.

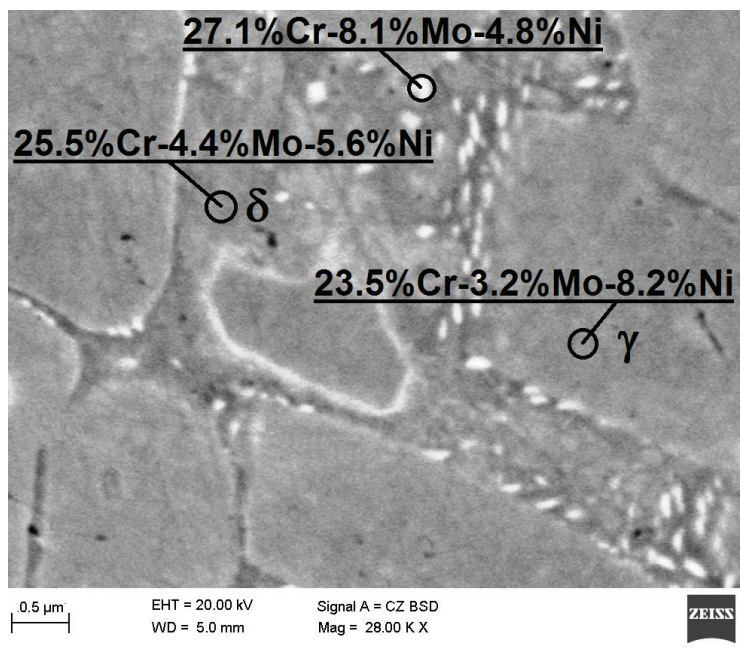

Figure 9. Detail of precipitates in the weld metal heat treated at $650^{\circ} \mathrm{C}$ for $60 \mathrm{~min}$. Qualitative results of EDS analysis of selected areas are presented. similar to that of Figures $8 b-d^{24}$. Another possible phase is the metastable $\chi$ phase, although some authors have reported its interval of precipitation between $700{ }^{\circ} \mathrm{C}$ and $900{ }^{\circ} \mathrm{C}^{23,25}$. Finally, the aging between 650 and $1000^{\circ} \mathrm{C}$ may also cause the precipitation of sigma $(\sigma)$, which is the most studied of the intermetallic phases in austenitic-ferritic steels. It appears in a tonality less brilliant than $\mathrm{R}$ and $\chi$, since it has less Mo than these two phases.

The behavior of the tensile properties with the duration of heat treatment are shown in Figures 10 and 11. All fractures occurred in the base metal, as also shown in Figure 10. Despite of the decrease of peak hardness in the HAZ, yield and ultimate strengths were not affected by the heat treatment. On the other hand, the elongation has decreased with the increase of the heat treatment duration, probably due to the intermetallics precipitation. Curiously, the reduction of area did not show the same trend of the elongation. The $\sigma_{\mathrm{Y}}$ and $\sigma_{\mathrm{UTS}}$ of the base metal (670 $\mathrm{MPa}$ and $798 \mathrm{MPa}$, respectively), also shown in Figure 10, were slightly superior to the welded joint. 


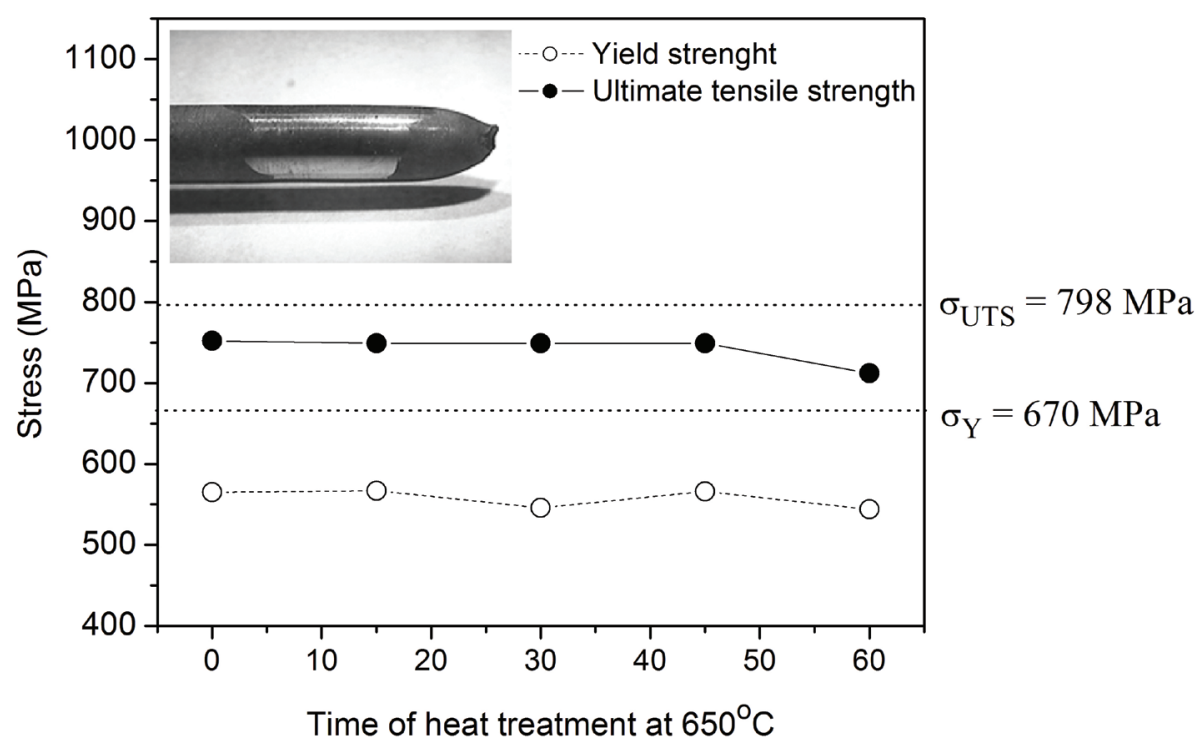

Figure 10. Variation of $0.2 \%$ yield limit and ultimate tensile strength with time of PWHT.

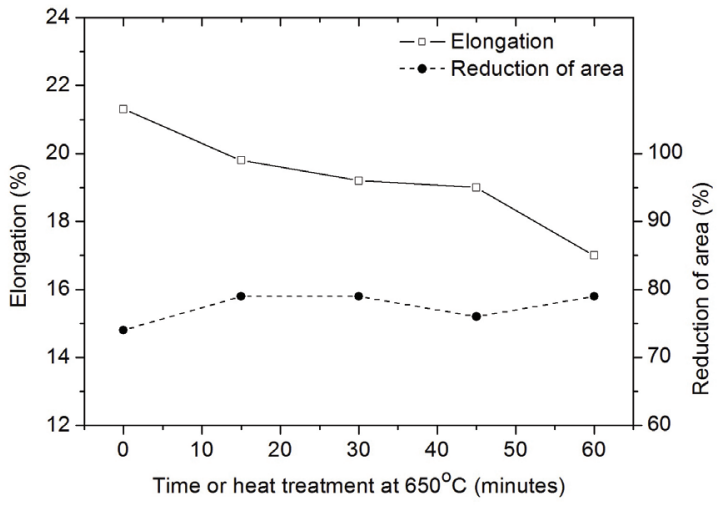

Figure 11. Variation of elongation and reduction of area with time of PWHT.

\section{Conclusions}

Welding of supermartensitic steel $13 \% \mathrm{Cr}$ was performed with GTAW using superduplex steel $(25 \% \mathrm{Cr}-9 \% \mathrm{Ni}-4 \% \mathrm{Mo}-$ $0.29 \% \mathrm{~N})$, without pre-heating. The analysis of the welded joint and the investigation on the post weld heat treatment (PWHT) at $650{ }^{\circ} \mathrm{C}$ allowed to obtain the following conclusions:

- Peaks of 350 HV15 of hardness were measured in the HAZ of the last pass, before PWHT.

\section{References}

1. Olden V, Thaulow $\mathrm{C}$ and Johnsen R. Modelling of hydrogen diffusion and hydrogen induced cracking in supermartensitic and duplex stainless steels. Materials \& Design. 2008; 29(10):19341948. http://dx.doi.org/10.1016/j.matdes.2008.04.026.

2. Park ES, Yoo DK, Sung JH, Kang CY, Lee JH and Sung JH. Formation of reversed austenite during tempering of $14 \mathrm{Cr}-7 \mathrm{Ni}$ -
- The root pass and middle passes weld metal contained an excess of austenite (around 75\%). The weld metal of the last passes contained approximately $60 \%$ of austenite.

- Heat treating at $650{ }^{\circ} \mathrm{C}$ for 30 minutes or more decreased the peak of hardness to about $299 \mathrm{HV}$ in the HAZ of the last pass. Heat treating for 15 minutes did not decrease significantly the peak of hardness.

- PWHT provoked the precipitation of deleterious phases in the $\gamma / \delta$ boundaries and inside the ferrite phase. The precipitates are Mo-rich compounds, such as $\mathrm{R}\left(\mathrm{Fe}_{2} \mathrm{Mo}\right)$, sigma $(\sigma)$ and chi $(\chi)$ phases.

- The tertiary precipitation caused the decrease of impact toughness at $-46{ }^{\circ} \mathrm{C}$ with the increase of time of PWHT. Despite of this, the specimen treated for 60 minutes showed a ductile behavior with impact energy superior to the minimum acceptable value (27J).

- The elongation measured in tensile tests decreased with the increase of PWHT time, due to the intermetallic precipitation. The other tensile properties remained stable with PWHT till 60 minutes.

\section{Acknowledgements}

Authors acknowledge the Brazilian research agencies CAPES, CNPq, and FAPERJ for the financial support.

0.3Nb-0.7Mo-0.03C super martensitic stainless steel. Metals and Materials International. 2004; 10(6):521-525. http:// dx.doi.org/10.1007/BF03027413.

3. da Silva GF, Tavares SSM, Pardal JM, Silva MR and de Abreu HFG. Influence of heat treatments on toughness and sensitization of a Ti-alloyed supermartensitic stainless steel. Journal of Materials Science. 2011; 46(24):7737-7744. http:// dx.doi.org/10.1007/s10853-011-5753-8. 
4. Carrouge D, Bhadeshia HKDH and Woollin P. Effect of $\delta$-ferrite on impact properties of supermartensitic stainless steel heat affected zones. Science and Technology of Welding \& Joining. 2004; 9(5):377-389. http://dx.doi. org/10.1179/136217104225021823.

5. Bala Srinivasan P, Sharkawy SW and Dietzel W. Hydrogen assisted stress-cracking behaviour of electron beam welded supermartensitic stainless steel weldments. Materials Science and Engineering A. 2004; 385(1-2):6-12. http://dx.doi. org/10.1016/j.msea.2004.03.029.

6. Pereda MD, Gervasi CA, Llorente CL and Bilmes PD. Microelectrochemical corrosion study of super martensitic welds in chloride-containing media. Corrosion Science. 2011; 53(12):3934-3941. http://dx.doi.org/10.1016/j. corsci.2011.07.040

7. Gesnouin C, Hazarabedian A, Bruzzoni P, Ovejero-Garcia J, Bilmes $\mathrm{P}$ and Llorente $\mathrm{C}$. Effect of post-weld heat treatment on the microstructure and hydrogen permeation of $13 \mathrm{crNiMo}$ steels. Corrosion Science. 2004; 46(7):1633-1647. http:// dx.doi.org/10.1016/j.corsci.2003.10.006.

8. Bilmes PD, Solari M and Llorente CL. Characteristics and effects of austenite resulting from tempering of $13 \mathrm{Cr}-\mathrm{NiMo}$ martensitic steel weld metals. Materials Characterization. 2001; 46(4):285-296. http://dx.doi.org/10.1016/S10445803(00)00099-1.

9. Divya M, Das CR, Ramasubbu V, Albert SK and Bhaduri AK. Improving 410NiMo weld metal toughness by PWHT. Journal of Materials Processing Technology. 2011;211(12):2032-2038. http://dx.doi.org/10.1016/j.jmatprotec.2011.06.024.

10. Neubert R, Reuter J, El Mahalawy N, Hoffmeister H and Hoffmann R. Effect of welding technique on weld morphology and hardness of supermartensitic $13 \% \mathrm{Cr}$ steels. Materials Science and Technology. 2004; 20(12):1551-1562. http:// dx.doi.org/10.1179/026708304X6068.

11. Thibault D, Bocher $\mathrm{P}$ and Thomas M. Residual stress and microstructure in welds of $13 \% \mathrm{Cr}-4 \% \mathrm{Ni}$ martensitic stainless steel. Journal of Materials Processing Technology. 2009; 209(4):2195-2202. http://dx.doi.org/10.1016/j. jmatprotec.2008.05.005.

12. Lippold J and Kotecki D. 2005. Welding metallurgy of stainless steels. New Jersey: Willey Interscience.

13. American Society for Testing and Materials - ASTM. ASTM E-23-12: standard test methods for notched bar impact testing of metallic materials. West Conshohocken; 2012.

14. American Society for Testing and Materials - ASTM. ASTM A-370-12: standard test methods and definitions for mechanical testing of steel products. West Conshohocken; 2012.
15. American Society for Testing and Materials - ASTM. ASTM E-562-01: standard test method for determining volume fraction by systematic manual point count. West Conshohocken; 2001.

16. Ramirez JE. Weldability evaluation of supermartensitic stainless steel pipes. Welding Journal. 2007; 86:125-134.

17. Yayla P, Kaluc E and Ural K. Effects of welding processes on the mechanical properties of HY-80 steel weldments. Materials \& Design. 2007; 28(6):1898-1906. http://dx.doi.org/10.1016/j. matdes.2006.03.028.

18. NACE International. ANSI/NACE MR0175/ISO 15156: petroleum and natural gas industries. Materials for use in $H 2 S$ containing environments in oil and gas production. Houston; 2002.

19. Standards Norway. Norsok Standard M-601: welding and inspection of piping (edition 5). Norway; 2008. $</ \mathrm{std}>$.

20. Pardal JM, Tavares SSM, Fonseca MPC, Souza JA, Vieira LM and Abreu HFG. Deleterious phases precipitation on superduplex stainless steel UNS S32750: characterization by light optical and scanning electron microscopy. Materials Research. 2010; 13(3):401-407. http://dx.doi.org/10.1590/ S1516-14392010000300020.

21. Pohl M, Storz O and Glogowski T. Effect of intermetallic precipitations on the properties of duplex stainless steel. Materials Characterization. 2007; 58(1):65-71. http://dx.doi. org/10.1016/j.matchar.2006.03.015.

22. Dobranszky J, Szabo PJ, Berecz T, Hrotko V and Portko M. Energy-dispersive spectroscopy and electron backscatter diffraction analysis of isothermally aged SAF 2507 type superduplex stainless steel. Spectrochimica Acta Part B: Atomic Spectroscopy. 2014; 59(10-11):1781-1788.

23. Gunn RN. Duplex stainless steels: microstructure, properties, and applications. Cambridge: Abington Publishing; 2003.

24. Hwang TH, Kim JH, Kim KH, Moon WJ and Kang CY. Effect of R-phase on impact toughness of 25Cr-7Ni-4Mo super duplex stainless steel. Metals and Materials International. 2014; 20(1):13-17. http://dx.doi.org/10.1007/s12540-014-1004-2.

25. Escriba DM, Materna-Morris E, Plaut RL and Padilha AF. Chi-phase precipitation in a duplex stainless steel. Materials Characterization. 2009; 60(11):1214-1219. http://dx.doi. org/10.1016/j.matchar.2009.04.013.

26. Mélo EB, Magnabosco R and Moura Neto C. Influence of the microstructure on the degree of sensitization of a duplex stainless steel UNS S31803 aged at 650oC. Materials Research. 2013; 16(6):1336-1343. http://dx.doi.org/10.1590/S151614392013005000125 . 